doi $10.15826 /$ recon.2021.7.3.016

UDC 332.1, 330.15

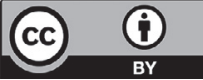

JEL R58 O14 L70

\title{
Russian oil and gas regions during the COVID-19 crisis and their digital transformation
}

\author{
R.R. Akhunov $₫$, L.R. Akhunova ${ }^{2}$, S.G. Marichev ${ }^{1}$, R.I. Nizamutdinov ${ }^{1}$ \\ ${ }^{1}$ Ufa Federal Research Centre, Russian Academy of Sciences, Ufa, Russia; akhunov@list.ru \\ ${ }^{2}$ Bashkir State University, Ufa, Russia
}

\section{ABSTRACT}

Relevance. One of the key long-term strategic goals of Russia's economic development is to increase the share of the digital and green economy in the gross product of the country and its regions. The recession caused by the pandemic has brought to the forefront the challenges of digitalization in the country's oil and gas sector, which was among the hardest hit sectors, and thus required significant effort on the part of regional governments.

Data and methods. The study provides an overview of the Russian and international research literature on the ways to foster economic recovery and growth after the COVID-19 pandemic, including the publications of the United Nations and the World Economic Forum. Methodologically, the study relies on the empirical, general scientific methods and methods of economic statistics. We used in our calculations the data from the open-access statistical yearbook 'Russian Regions' published by Rosstat.

Results The study analyzed the challenges of digitalization faced by Russian oil and gas regions to show the need for institutional transformations on the national level. We also formulated some recommendations for the improvement of the evaluation of regional governments' digitalization efforts in the context of the COVID-19 pandemic and the more general evaluation of the digital transformation of regional economies.

Conclusions To stimulate economic growth of Russian oil and gas regions recovering from the pandemic, a viable strategy would be to place a greater emphasis on their sustainable and digital development. In the international rankings such as the EDGI Ranking presented annually by the United Nations Department of Economic and Social Affairs (UN DESA), Russia occupies a high position in terms of e-government services and digitalization in other spheres. Nevertheless, as far as the Russian oil and gas regions are concerned, there are considerable disparities in terms of digitalization. To accelerate digital transformation, we would highly recommend to improve the methods of evaluation of the digital progress in regional government, especially to include a set of indicators characterising regional governments' responses to the challenges posed by the COVID-19 pandemic.
\end{abstract}

\section{KEYWORDS}

oil and gas regions, digitalization of economy, regional informatization, technological modernization of the oil and gas industry, assessment of the digitalization of regional governments, COVID-19 pandemic, digital maturity indicators, evaluation of the digital sector

\section{ACKNOWLEDGEMENTS}

The research was conducted in execution of the state assignment of the Ministry of Science and Education of the Russian Federation given to the Ufa Federal Research Centre of the Russian Academy of Sciences (UFRC RAS).

\section{FOR CITATION}

Akhunov, R.R., Akhunova, L.R., Marichev, S.G., \& Nizamutdinov, R.I. (2021). Russian oil and gas regions during the COVID-19 crisis and their digital transformation. R-economy, 7(3), 179-191. doi: 10.15826/recon.2021.7.3.016

\section{Российские нефтегазовые регионы в период коронакризиса и их цифровая трансформация}

\author{
Р.Р. Ахунов ${ }^{1} \bowtie$, Л.Р. Ахунова ${ }^{2}$, С.Г. Маричев ${ }^{1}$, Р.И. Низамутдинов ${ }^{1}$ \\ ${ }^{1}$ Уфимский федеральный исследовательский иентр Российской академии наук, Уфа, Pоссия; akhuпоv@list.ru \\ ${ }^{2}$ Башкирский государственный университет, Уфа, Россия
}

\section{АННОТАЦИЯ}

Актуальность. Одной из стратегических целей экономического развития Российской Федерации в долгосрочной перспективе является повышение доли цифровой и «зелёной» экономики в валовом продукте страны и её регионов. Экономический спад, вызванный пандемией новой коронавирусной инфекции COVID-19, актуализирует задачи цифровизации нефтегазовых отраслей российской экономики как одних из наиболее пострадавших, тем самым предъявляя вызовы региональным органам государственной власти и управления.

Данные и методы. Для проведения исследования были использованы и проанализированы российские и зарубежные работы по теме преодоления последствий мирового кризиса, вызванного пандемией новой коро-

\section{КЛЮЧЕВЫЕ СЛОВА}

нефтегазовые регионы, цифровизация экономики, региональная информатизация, технологическая модернизация нефтегазовой отрасли, оценка цифровизации региональных правительств, пандемия COVID-19, показатели цифровой зрелости, оценка цифрового сектора экономики 
навирусной инфекции COVID-19, в том числе публикации Организации Объединенных Наций и Всемирного экономического форума. В работе были использованы эмпирические, общенаучные и экономико-статистические методы исследования. Аналитические расчеты проведены по материалам статистического сборника «Регионы России», находящегося в открытом доступе на официальном сайте Росстата.

Результаты. В рамках исследования был произведен анализ проблем цифровизации, стоящих перед нефтегазовыми регионами. Обоснована необходимость институциональных преобразований на государственном уровне. Даны рекомендации по совершенствованию систем оценки цифровизации региональных правительств в условиях преодоления кризиса, вызванного пандемией COVID-19, и региональных экономик в целом.

Выводы. Для стимулирования экономического роста российских нефтегазовых регионов, восстанавливающихся после пандемии, необходимо сделать больший упор на их устойчивое и цифровое развитие. В международных рейтингах, таких как рейтинг EDGI, ежегодно представляемый Департаментом по экономическим и социальным вопросам ООН (ДЭСВ ООН), Россия занимает высокие позиции касательно электронного правительства и цифровизации в других сферах. Тем не менее, в российских нефтегазовых регионах существуют значительные различия в плане цифровизации. Чтобы ускорить цифровую трансформацию, мы настоятельно рекомендуем улучшить методы оценки цифрового прогресса в региональных органах власти, в особенности включить набор показателей, характеризующих реакцию региональных правительств на вызовы, создаваемые пандемией COVID-19.

\section{БЛАГОДАРНОСТИ}

Статья подготовлена в рамках выполнения плана НИР УФИЦ РАН по государственному заданию Министерства науки и высшего образования РФ.

\section{ДЛЯ ЦИТИРОВАНИЯ}

Akhunov, R.R., Akhunova, L.R., Marichev, S.G., \&

Nizamutdinov, R.I. (2021).

Russian oil and gas regions during the COVID-19 crisis and their digital transformation. R-economy, 7(3), 179-191. doi: 10.15826/recon.2021.7.3.016

\section{Introduction}

The effects of the 2020 pandemic varied significantly across different industries: while the traditional industries were hit the hardest by the coronacrisis, tech giants reported soaring profits. The sectors that were most affected by the pandemic were aviation, public services and the oil and gas industry.

In 2020, the double blow of the COVID-19 pandemic and the oil price shock resulted in Russian oil and gas regions losing a significant part of their revenue. The budgets of such regions as the Yamalo-Nenets and Nenets autonomous districts, the republics of Bashkortostan, Tatarstan and Komi and Astrakhan region suffered the most as their tax and non-tax revenue dropped by more than $10 \%{ }^{1}$. Despite the unprecendented financial support from the federal government, the rise in public expenditure to fight the pandemic also turned oil and gas regions into the regions with the highest ratio of budget deficit to their own revenues: in Tumen region, for example, the deficit was 19.6\%, in the Yamalo-Nenets Autonomous District and Bashkortostan, $14.3 \%^{2}$. The production index for 2020 declined significantly in the service sector $(-17,3 \%$ in comparison with 2019) and the mining sector $(-7 \%)^{3}$.

Tipenko N.G. Analysis of the Implementation of Regional Budgets in 2020, p. 9. Retrieved from: https://www.eseur.ru/Files/file14395.pdf

${ }^{2}$ Ibid.

${ }^{3}$ Information for Monitoring of the Socio-Economic Situation in Russian Regions in January-December 2020. Retrieved from: https://rosstat.gov.ru/folder/11109/document/13259
In order to stay competitive, oil and gas regions have to keep up with the global trends such as digitalization and sustainable development. Digitalization can become a major driver for economic growth, but to achieve this, it is first necessary to ensure ICT diffusion across Russian regions.

This research aims to demonstrate the key role played by digitalization and environmentalization in the recovery of the Russian oil and gas regions from the pandemic. This research purpose is determined by the events of the pandemic year of 2020, which saw a major rise in environmental awareness in all spheres, including the global economy. Many decisions taken in this period point to the long-standing nature of this trend. During the lockdowns many people had to spend more time in front of their computer screens, which led them to appreciate the benefits of digitalization, in particular, its potential as an instrument of cost-cutting and business development.

The above-described research objective determined the following research tasks:

- describe the reasons why technological modernization in the oil and gas industry is essential for the country's economic growth;

- explore the questions of digitalization in regional governance and propose measures for the improvement of the methodology used to evaluate e-government services in Russian regions and the performance of regional executive governments during the COVID-19 pandemic; 
- analyze the existing evaluation methodologies and formulate recommendations for their improvement.

\section{Literature review}

The impact of the pandemic on regions specializing in oil and gas production is discussed in a recent study by Akhunov and Nizamutdinov (2020), which examines the situation in the corporate sector during the 2020 pandemic and sheds light on the long-term risks that stem from the long-term sustainable development trends in global economy. Gadzhiev et al. (2021), Lanshina et al. (2020) and Zhiznin et al. (2021) discuss the impact of the pandemic on environmentalization and digitalization and the major role these trends play in the future sustainable economic development. They also highlight the mutual influence of digitalization and environmentalization.

Oil and gas regions undoubtedly present a specific case of resource-dependent regions. In research literature, there is no general agreement as to the quantitative criteria of a 'resource-dependent' or 'oil and gas region'; instead, preference is given to qualitative criteria: for example, the distinctive feature of these regions is that their economy is reliant on the exploitation of natural resources (in our case oil and gas reserves) (see, for example, Kryukov et al., 2017). Another distinctive feature pointed out by some authors is the export orientation of this sector (Levin et al., 2015).

The development of the digital economy is discussed in the UN's 2019 report, the report of the U.S. Bureau of Economic Analysis (BEA) of 2019, and in the study of Tatarinov (2016). Brynjolfsson and Collis (2017) propose a methodology for the evaluation of the digital economy's contribution to economic growth. This methodology is underpinned by the idea that the recent growth in the digital economy has determined significant welfare gains, which, however, are not reflected in GDP since many digital goods have zero price. It is proposed to measure the digital economy by using the indicator GDP-B, which quantifies the benefits rather than costs of free digital goods and services.

The indicators for measuring the progress of the digital transformation in Russian cities and regions are described in the reports of the Higher School of Economics (2018) and the National Research Institute of Technologies and Communications (NIITC). Despite the rapidly increasing share of companies implementing digital strategies, the extent of digitalization on the national and regional levels still leaves much to be desired. Among the most prominent aspects of the digital transformation during the COVID-19 pandemic is the delivery of the increasing number of public services in the electronic form (Chizada et al., 2021).

Our study relies on the approach to studying e-government and the principles of its operation described in the works of Fang (2002) and Ndou (2004). Ndou, quoting the UN and ASPA's report, defines e-government as 'the public sector's use of the most innovative information and communication technologies, like the Internet, to deliver to all citizens improved services, reliable information and greater knowledge in order to facilitate access to the governing process and encourage deeper citizen participation' (Ndou, 2004, p. 4). Institutional transformations linked to the development of e-government are discussed by Sei-fert (2003), who highlights the increasing speed of digital transformation in the activities of governments and the wider range of e-government solutions available nowadays. The use of digital solutions for delivering government services during the pandemic is also considered by Ahmed et al. (2020) and Shahroz et al. (2021).

\section{Data and methods}

The study relies on empirical and general scientific methods to investigate the role of oil and gas regions in national economic growth. To analyze the indicators of the digital maturity of oil and gas regions, the methods of economic statistics were applied.

The study comprised the following stages: first, we analyzed the factors of economic growth in Russia during the pandemic and tested the hypothesis about the need to modernize oil and gas enterprises in Russia. Second, we evaluated the level of digital maturity of executive government bodies and identified the key priorities in advancing the digitalization of regional executive governments. Third, we analyzed the existing methods of digitalization evaluation in different sectors of national economy and formulated our recommendations for the advancement of digital transformation in the Russian economy.

In this study, oil and gas regions in Russia are defined as the regions with the total share of production of oil, gas, coke and petroleum products exceeding $15 \%$ of gross regional product (GRP). $15 \%$ of GRP is quite a substantial figure, which shows a significant impact that the sector has on regional economies. In the structure of GRP of 
regions, there are sectors and subsectors whose share exceeds $15 \%$. Normally a region has just one or, in rare cases, two such sectors, which play a key role in this region's economy. Our choice of $15 \%$ as the lower threshold was partially determined by the available empirical data since it is at this level that most of the disparities between the oil and gas regions tend to occur (see Fig. 1).
To avoid data duplication, that is, the data for autonomous districts being considered twice - as separate regions and as parts of larger regions, we analyzed autonomous districts separately from the regions they are part of and in the analysis of larger regions excluded the data on autonomous districts. As a result, our analysis covered in total 19 Russian oil and gas regions (see Table 1).

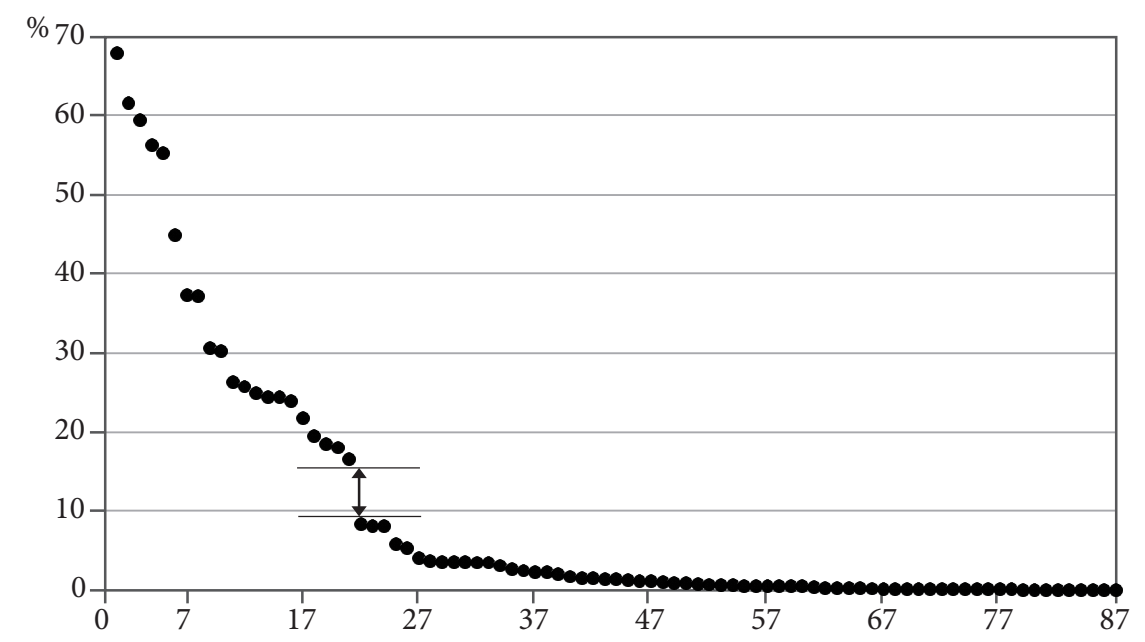

Figure 1. Share of oil, gas, coke and petroleum products in GRP of Russian regions in 2019,\% Source: The authors' calculations were based on the data from Rosstat for 2019 (Sectoral Structure of Gross Value Added of the Regions of the Russian Federation in 2019. Retrieved from: https://rosstat.gov.ru/storage/mediabank/DA162kUL/ Struktura19.xlsx) and from the Statistical Yearbook 'Russian Regions 2020' (Russian Regions. Socio-Economic Indicators in 2020. Retrieved from: https://rosstat.gov.ru/storage/mediabank/LkooETqG/Region Pokaz 2020.pdf)

Russian oil and gas regions

\begin{tabular}{|l|c|c|c|}
\hline \multicolumn{1}{|c|}{ Oil and gas regions } & $\begin{array}{c}\text { Share of oil and gas } \\
\text { production in GRP, \% }\end{array}$ & $\begin{array}{c}\text { Share of coke and } \\
\text { refined petroleum } \\
\text { products in GRP, \% }\end{array}$ & $\begin{array}{c}\text { Total share of oil, gas, } \\
\text { coke and petroleum } \\
\text { products in GRP, \% }\end{array}$ \\
\hline Nenets Autonomous District & 68.03 & 0 & 68.03 \\
\hline Yamalo-Nenets Autonomous District & 56.97 & 4.54 & 61.51 \\
\hline Khanty-Mansiysk Autonomous District & 58.04 & 1.51 & 59.55 \\
\hline Sakhalin region & 56.43 & 0.06 & 56.50 \\
\hline Astrakhan region & 42.25 & 2.44 & 44.69 \\
\hline Komi Republic & 34.69 & 2.82 & 37.50 \\
\hline Orenburg region & 34.03 & 3.40 & 37.43 \\
\hline Tatarstan Republic & 25.37 & 5.23 & 30.60 \\
\hline Perm region & 20.29 & 9.99 & 30.29 \\
\hline Tomsk region & 24.04 & 1.95 & 25.98 \\
\hline Udmurt Republic & 24.45 & 0.24 & 24.68 \\
\hline Tyumen region (autonomous districts excluded) & 17.21 & 6.99 & 24.21 \\
\hline Omsk region & 0 & 24.20 & 24.20 \\
\hline Republic of Sakha (Yakutia) & 23.63 & 0.13 & 23.76 \\
\hline Irkutsk region & 20.98 & 0.67 & 21.65 \\
\hline Krasnoyarsk region & 18.61 & 0.87 & 19.49 \\
\hline Samara region & 16.79 & 1.82 & 18.61 \\
\hline Volgograd region & 4.95 & 13.23 & 18.18 \\
\hline Republic of Bashkortostan & 1.74 & 15.10 & 16.84 \\
\hline
\end{tabular}

Source: The authors' calculations were based on the data from Rosstat for 2019 (Sectoral Structure of Gross Value Added of the Regions of the Russian Federation in 2019. Retrieved from: https://rosstat.gov.ru/storage/mediabank/DA162kUL/Struktura19.xlsx) and from the Statistical Yearbook 'Russian Regions 2020' (Russian Regions. Socio-Economic Indicators in 2020. Retrieved from: https://rosstat.gov.ru/storage/mediabank/LkooETqG/Region Pokaz 2020.pdf). 
This study provides an overview of the Russian and international research literature on the ways to create economic recovery and growth after the COVID-19 pandemic, including the publications of the United Nations and the World Economic Forum. For our calculations, we used the data from the statistical yearbook 'Russian Regions' for 2020, which is publicly available on the official website of Rosstat.

\section{Results}

In this study, we intend to analyze the digitalization rates of regional governments and regional economies in general. We also seek to demonstrate the pivotal role of the oil and gas sector in the digitalization of the Russian economy.

\section{Digitalization of Russian oil and gas regions as a factor of the country's economic growth}

In accordance with the report of the World Economic Forum, most economic growth potential in the post-crisis period will be enjoyed by the 'green tech' companies generating added value from digital technologies used to create a greener future ${ }^{4}$.

The oil and gas industry is crucial for many Russian regions and for the country in general. Lately, the industry has managed to make a certain progress in terms of technological development, which includes such spheres as digital transformation and sustainability. For example, according to the Deputy Minister of Energy Pavel Sorokin, the expected aggregate effect of using AI technologies in the oil industry will be about 5.4 trillion roubles in the period between 2025 and $2040^{5}$.

Many Russian industrial organizations are planning to invest billions of roubles into modernization of their businesses. Thus, global trends present challenges not only to companies striving for modernization but also companies generating demand on the market of digitalization and sustainability. Investment into the digital and green economy through the multiplier effect can fuel growth in other sectors of economy. On the other hand, these funds may also be spent elsewhere to purchase modern equipment and technologies. Oil and gas regions play a special role in digita-

${ }^{4}$ Chief Economists Outlook 2021 / World Economic Forum (13.06.2021). Retrieved from: https://www.weforum.org/ reports/chief-economists-outlook-2021

${ }^{5}$ Presentation of Pavel Sorokin at the congress 'Innovation Practice: Science and Business'. Retrieved from: https:// $\underline{\text { minenergo.gov.ru/node/19641 }}$ lization as they can help drive the advancement of digital and environmental technologies due to the sheer scale of their economies and the opportunities opened by digitalization in the oil and gas sector. Digital technologies can be used in all phases of oil production: from exploration to sale. According to expert evaluations, the global market of digital technologies used for oil exploration and extraction is worth 2 billion dollars a year ${ }^{6}$. After 2021, the share of Russian companies in this market will rise from 5 to $6-7 \%$. Moreover, oil and gas regions are now seeking to deal with the risks to their security associated with the global transition to renewables. Digital technologies can give oil and gas regions a competitive edge that they need so much to stay afloat ${ }^{7}$.

The possible benefits of digital transformation in the oil and gas industry, which will turn this sector into the locomotive of digitalization in the Russian economy, are as follows:

1. Oil reserves are being depleted faster than they are being discovered and new oil fields are now harder to find (Shmal, 2020). Digital solutions will increase the efficiency of oil exploration. For example, Russian companies such as Tatneft and Gazpromneft are already using the digital twin technology and AI for oil exploration. Since the areas with milder climatic conditions and easily minable oil deposits are already known, the newly found deposits are usually located in the areas that are difficult to access, which leads to a rise in the use of automation in the oil and gas industry.

2. More and more oil reserves are becoming stranded, which brings to the fore the question of cost-cutting in their exploration. Digital solutions increase the profitability of stranded oil production (Dmitrievsky, 2020) and enhance oil recovery (the reserves-to-production ratio). Quite illustrative in this respect is the US Shale Revolution, which would not have been possible without digital technologies. According to the Russian Ministry of Energy, measures to support digitalization in the oil industry will cut the exploration costs by up to $15 \%$ and cut the costs of commissioning of new

${ }^{6}$ Digital Economy Report of the United Nations. Value Creation and Capture: Implications for Developing Countries (2019) United Nations Conference on Trade and Development. Retrieved from: https://unctad.org/en/PublicationsLibrary/ der2019 overview ru.pdf

Research Focus: Digitalization of the Oil Sector (20.06.21). Retrieved from: https://iz.ru/1126511/valerii-voronov/nauchnyi-aktcent-kak-neftianaia-otrasl-perekhodit-na-tcifrovye-tekhnologii 
facilities ${ }^{8}$. In monetary terms, the amount of cost saving would be about 700 billion roubles a year9.

The comprehensive digitalization of oil extraction can be illustrated by the recent case of the digital oilfield launched by Rosneft in Bashkortostan in 2019, which was the first project of this kind in Russia. A digital oilfield means permanent data collection at all stages of the oilfield's lifecycle from exploration to mining - and centralized data processing on a digital platform for enhanced efficiency and profitability. According to Rosneft, the use of digital technologies has led to an increase in the number of remotely controlled objects by almost $60 \%$. The company has also managed to cut its logistics costs by $5 \%$ and increase the energy efficiency of oil extraction by $5 \%{ }^{10}$. In monetary terms, the effect from the use of digital solutions at the oilfield in Bashkortostan was estimated as 1 billion roubles a year ${ }^{11}$.

3. It is necessary to raise the environmental sustainability standards of oil and gas production. The oil and gas sector has a huge infrastructure, which encompasses a myriad of assets but is also vulnerable to damage and may be prone to malfunctions (Zemtsov et al., 2020). Automation of equipment and infrastructure diagnostics helps prevent or mitigate the consequences of equipment failure, including the negative environmental impact of pollution leaks, and increase the energy efficiency and productivity of labour.

Investors, from private investors to investment funds and governments, now tend to be attracted more by green and digital technologies. According to $\mathrm{PwC}, 31 \%$ of investors take into account the climate change factor in their decision-making and $41 \%$, the factor of cybersecurity. $83 \%$ and $86 \%$ of investors respectively reported their concern about these questions ${ }^{12}$.

The use of digital solutions to address the challenges of environmental security may well serve as one of the instruments for attracting investors. Thus, digitalization and environmentalization go hand in hand.

\footnotetext{
${ }^{8}$ Presentation of Pavel Sorokin at the meeting of the Working Group 'Digital Transformation of the Oil and Gas Industry'. Retrieved from: https://minenergo.gov.ru/node/19270

${ }^{9}$ Ibid.

${ }^{10}$ Rosneft Launches the Project 'Digital Deposit' in Bashkiria. Retrieved from: https://www.rosneft.ru/press/news/ item/195043/

${ }^{11}$ Ibid.

12 ESG-Factors in Investment. PWC Report of 2019. P.15. (19.06.21). Retrieved from: https://www.pwc.ru/ru/sustainability/assets/pwc-responsible-investment.pdf
}

Moreover, in view of the current situation in Russia, the trend for sustainability is more relevant than ever. Climate change has not left Russia unaffected, especially its vast permafrost areas. The thawing permafrost, according to the Ministry of Natural Resources, depending on the speed of the melt, may lead to the losses of approximately 5 trillion roubles by $2050^{13}$. Climate change will have a detrimental impact on transport and industrial infrastructure, production assets and so on.

Global warming, however, was not the only challenge faced by Russia in 2020: in the same year, the country went through a series of natural and anthropogenic disasters - from droughts and wildfires to the spills of oil and hazardous substances. Apart from the damage inflicted on the natural environment and human communities, global warming has detrimental economic effects: hundreds billions of roubles were spent on emergency response and recovery efforts to minimize the damage. The negative anthropogenic impact on the environment in Russia largely stems from the country's economic dependence on raw materials production as well as the use of obsolete and outdated facilities and equipment. Therefore, the most effective response to these challenges would be the diversification of the national economy and technological modernization. Digitalization could be an answer to many of these questions, including the need to enhance the efficiency of nature conservation activities.

\section{Enhancement of regional governments' digital maturity}

Innovation policy-making plays a key role in providing institutional support for digital transformation, such as federal and regional programs, which include subsidies and preferential lending to organizations implementing digital and green technologies. According to the UN, there is a strong positive correlation between economic growth and the level of digitalization in public administration ${ }^{14}$. The growth in the digital economy strongly correlates $(0.92)$ with e-government development (Zhao et al., 2015). Therefore, the task of increasing the digital maturity of the Russian government may become the backbone

${ }_{13}$ Press-Service of the Ministry of Natural Resources of Russia. By 2024 the State System of Permafrost Monitoring will Cover the Whole Territory of the Cryolithic Zone. Retrieved from: https://clck.ru/W79gm

${ }^{14}$ E-Government Survey 2020 (15.06.21). Retrieved from: https://publicadministration.un.org/egovkb/en-us/Reports/UN-E-Government-Survey-2020 
of successful technological modernization of the national economy.

To stimulate the digitalization of public administration in Russia, it is necessary to monitor and evaluate the progress in this sphere.

On the international level, digital efforts of national governments are measured by the United Nations with the help of the composite indicator E-Government Development Index (EDGI). In 2020, Russia ranked $36^{\text {th }}$ in this ranking ${ }^{15}$. The EDGI consists of three subindices measuring the level of online services, the development status of telecommunication infrastructure and human capital. In 2020, the EDGI of the Russian Federation was 0.8244 , which is a quite impressive result. In the last decade, this figure grew from 0.5136 in 2010 to 0.7345 in 2021 . However, despite the absolute growth in this indicator, in the same period, in the ranking Russia dropped from $27^{\text {th }}$ in 2012 to $36^{\text {th }}$ in 2020 . Our calculations show that the sphere of telecommunications infrastructure in Russia still holds much potential for improvement since the value of this subindex is 0.77 , which is lower than the values of other subindices - that of online services (0.82) and human capital development (0.88).

In order to ensure a stable progress in the sphere of e-government, it is important to evaluate the level of the digital maturity of public administration not only on the federal but also on the region level.

Since 2016, the level of digitalization in Russian regions has been monitored with the help of the regional digitalization index. On several occasions, the methodology of index calculation has been revised. Eventually, the decision was taken to introduce another index - the National Index of Digital Economy Development, which is currently being devised by the Ministry for Digital Development, Communication and Mass Media within the national project 'Digital Economy'16.

To measure the level of regional governments' digitalization, it is also possible to apply the methodology proposed by the Ministry for Digital Development. This methodology focuses on assessing the performance of the chief executive officers of regional governments. In total, the methodology encompasses 20 indicators, including the

${ }^{15}$ E-Government Survey 2020 (15.06.21). Retrieved from: https://publicadministration.un.org/egovkb/en-us/Reports/UN-E-Government-Survey-2020

16 Project 'Digital Public Administration' (15.06.2021). Retrieved from: https://digital.gov.ru/ru/activity/directions digital maturity of regional governments ${ }^{17}$. In its turn, digital maturity is evaluated with the help of 34 subindicators for the four key areas: education, municipal services and construction, public transport and public administration ${ }^{18}$.

If we compare the above-described Russian methodology with that of the United Nations, the following observations can be made:

- the Russian methodology uses a larger number of indicators, which makes the process of data collection and calculations more difficult, although there is a slight improvement in the evaluation accuracy. Moreover, a large number of indicators makes calculations less transparent;

- the Russian methodology aims to evaluate the level of digitalization in different spheres while the UN's methodology focuses on different digitalization areas;

- both methodologies have no indicators to estimate the effects of the COVID-19 recovery measures.

In our view, in order to stimulate the development of e-government in the Russian Federation, the following tasks should be addressed:

- first, it is necessary to simplify the indicator system, bringing it closer to the international methodology, in order to make the two systems more comparable and to ensure compliance with the most advanced global practices in the digitalization of the public sector;

- second, as the estimations of international experts show, the development of the ICT infrastructure should be prioritized and the corresponding evaluation methodology should be introduced;

- third, it is essential to devise methods for the evaluation of e-government development in the light of the COVID-19 recovery measures.

There is evidence that the mortality rates during the pandemic were directly related to the efficiency of national and regional governments

17 The Decree of the President of the Russian Federation of 04.02.2021 No. 68 'On the Evaluation of the Efficiency of the Chief Executives (Chief Executive Officers of the Government) of the Subjects of the Russian Federation and of the Performance of the Executive Bodies of the Subjects of the Russian Federation'

18 Decree of the Government of the Russian Federation of 3.04.2021 No. 542 'On the Approval of the Methodology of Calculation of the Indicators of Performance of the Chief Executives (Chief Executive Officers of the Government) of the Subjects of the Russian Federation and of the Performance of the Executive Bodies of the Subjects of the Russian Federation, and the Annulment of Certain Acts of the Decree of the Government of the Russian Federation of 17 July 2019 No. 915. 
(Chizada et al., 2021). Moreover, during the pandemic, increasing technical demands were placed on governments (Ahmed et al., 2020; Shahroz et al., 2021), and these demands should be reflected in the evaluation systems.

To save time, a simpler evaluation design can be used. For example, we can use a limited number of indicators, including the following:

- the number and quality of government agencies: statistics, security level;

- the number of inquiries submitted through e-government portals;

- the amount and quality of open-access data on the activities of government agencies;

- the number of mentions of regional government agencies in the mass media, Internet and social media in the context of digitalization and the volume (or number) of searches for particular keywords containing the names of government agencies.

To evaluate how efficiently the government used digital technologies to confront the COVID-19 pandemic, we need to look at the indicators shown in Table 2 below.

\section{Evaluation of the digitalization of Russian oil and gas regions}

It should be noted that the evaluation of e-government development is not the only priority and that there are other important tasks linked to digital development in the economic sphere.
Unfortunately, the existing methodologies fail to provide a complete picture of the digitalization in the socio-economic sphere.

The most widespread approach is to look at the share of $R \& D$ expenditure as a percentage of national GDP. For example, the UN's 'Digital Economy Report 2019' estimates the size of the digital economy as $4.5-15.5 \%$ of world GDP. In Russia, this indicator is significantly lower - only $1.7 \%$ (it is planned to raise this indicator level to $5 \%$ by 2024). However, the drawback of this approach is that it focuses only on the effort invested into the digital transformation and says little about its outcomes. Among the leading technologies that power a large part of innovation are robotics and sensor devices, machine learning, blockchain, digital twins and so on. There is another indicator - value added per rouble of capital invested into digitalization and the creation of the digital economy - but it is not considered as the main one (Ahmad \& Ribarsky, 2017).

There are objective impediments to digitalization on the regional level, which include the following:

1) lack of funding for digital development on the federal and especially regional levels;

2) digital inequality (the disparities in the development of digital and information technologies);

3) lack of education programs and disciplines related to the professions that actually exist but still remain outside the legal system;

Indicators for measuring the digital transformation during the COVID-19 pandemic

Table 2

\begin{tabular}{|l|l|}
\hline \multicolumn{1}{|c|}{ Digitalization areas } & \multicolumn{1}{c|}{ Indicators } \\
\hline $\begin{array}{l}\text { Information disclosure and } \\
\text { measures to fight COVID-19 } \\
\text { misinformation (infodemic) }\end{array}$ & $\begin{array}{l}\text { - availability of portals, mobile apps and platforms in social media to connect and inform } \\
\text { citizens; }\end{array}$ \\
\hline $\begin{array}{l}\text { Regional and interministerial } \\
\text { cooperation }\end{array}$ & - the number of video conferencing services used; \\
- the number of remote working solutions installed;
\end{tabular}

Source: compiled by the authors 
4) lack of centralized processing of the data on the ongoing digital projects; lack of exchange of know-how experience and expertise;

5) state industrial enterprises' lack of motivation to digitize (except for the agricultural sector);

6) compartmentalisation of information on digitalization due to mass media's catering to regional audiences.

Our calculations show significant disparities between oil and gas regions in terms of their ICT development (Table 3), in particular regarding the amount of digital transformation spending. In 2019 , in this indicator, the leading regions were the Republic of Tatarstan, Khanty-Mansiysk Autonomous District and Samara region. The lowest level in this indicator was shown by the Nenets Autonomous District (764 mln roubles), which is only $2 \%$ of Tatarstan's spending on technology. The majority of oil and gas regions are below the national average in digital transformation indicators, including the share of organizations and households using PCs; the share of organizations using servers and cloud services and having websites. In terms of the number of connected devices per 1,000 people, all oil and gas regions, except for the Yamalo-Nenets Autonomous District, are considerably below the national average.

If we compare the data in Tables 1 and 3, the following pattern can be observed: the regions with the highest cumulative percentage of oil, gas,

Digital maturity indicators of Russian oil and gas regions

\begin{tabular}{|c|c|c|c|c|c|c|c|c|c|c|c|c|c|c|c|}
\hline & \multicolumn{4}{|c|}{$\begin{array}{l}\text { Use of ICT in organi- } \\
\text { zations (in \% of the } \\
\text { total number of orga- } \\
\text { nizations surveyed): }\end{array}$} & \multirow{2}{*}{$\begin{array}{c}\text { Use } \\
\text { of } \\
\text { the } \\
\text { In- } \\
\text { ter- } \\
\text { net, } \\
\%\end{array}$} & \multirow{2}{*}{$\begin{array}{c}\text { Own } \\
\text { web- } \\
\text { site, } \\
\%\end{array}$} & \multirow{2}{*}{$\begin{array}{l}\text { Num- } \\
\text { ber of } \\
\text { PCs } \\
\text { per } \\
100 \\
\text { emp- } \\
\text { loyees, } \\
\text { units }\end{array}$} & \multirow{2}{*}{$\begin{array}{c}\text { Use } \\
\text { of } \\
\text { spe- } \\
\text { cial } \\
\text { soft- } \\
\text { ware, } \\
\%\end{array}$} & \multirow{2}{*}{$\begin{array}{l}\text { Digital } \\
\text { transfor- } \\
\text { mation } \\
\text { spending, } \\
\text { mln rbs }\end{array}$} & \multirow[t]{2}{*}{$\begin{array}{c}\text { Use of } \\
\text { e-docu- } \\
\text { ment } \\
\text { flow }\end{array}$} & \multicolumn{3}{|c|}{$\begin{array}{c}\text { Use of PCs and } \\
\text { the Internet in } \\
\text { households, } \\
\text { percentage of } \\
\text { households }\end{array}$} & \multirow{2}{*}{$\begin{array}{c}\text { In- } \\
\text { ternet } \\
\text { access, } \\
\text { in \% } \\
\text { of the } \\
\text { total } \\
\text { popu- } \\
\text { lation } \\
\text { of the } \\
\text { region }\end{array}$} & \multirow{2}{*}{$\begin{array}{l}\text { Num- } \\
\text { ber of } \\
\text { con- } \\
\text { nected } \\
\text { devi- } \\
\text { ces per } \\
1,000 \\
\text { people }\end{array}$} \\
\hline & PCs & $\begin{array}{l}\text { Ser- } \\
\text { vers }\end{array}$ & LANs & \begin{tabular}{|c|} 
Cloud \\
ser- \\
vices
\end{tabular} & & & & & & & PC & $\begin{array}{c}\text { Inter- } \\
\text { net } \\
\text { access }\end{array}$ & $\begin{array}{l}\text { Broad- } \\
\text { band } \\
\text { Inter- } \\
\text { net } \\
\text { access }\end{array}$ & & \\
\hline Russian Federation & 93.5 & 53.8 & 63.5 & 28.1 & 91.2 & 51.9 & 51.0 & 85.9 & 2316831.4 & 70.0 & 69.4 & 76.8 & 73.2 & 85.6 & 2109.8 \\
\hline $\begin{array}{l}\text { Khanty-Mansi- } \\
\text { ysk Autonomous } \\
\text { District }\end{array}$ & 93.9 & 64.7 & 71.3 & 25.5 & 91.1 & 50.2 & 26.0 & 86.4 & 28057.2 & 68.9 & 73.1 & 86.2 & 83.2 & 93.5 & 2077.2 \\
\hline $\begin{array}{l}\text { Yamalo-Nenets } \\
\text { Autonomous } \\
\text { District }\end{array}$ & 90.6 & 61.9 & 70.0 & 23.8 & 87.3 & 48.6 & 29.0 & 84.0 & & 68.6 & 92.4 & 95.0 & 93.9 & 98.4 & 2442.0 \\
\hline Tatarstan Republic & 99.6 & 62.8 & 68.6 & 38.9 & 98.2 & 54.1 & 37.0 & 91.7 & & 75.9 & 65.6 & 78.1 & 73.8 & 91.2 & 1969.3 \\
\hline Orenburg region & 97.3 & 51.3 & 68.4 & 23.4 & 95.6 & 54.6 & 31.0 & 91.2 & 6994.5 & 77.0 & 78.8 & 87.9 & 86.1 & 90.0 & 1989.4 \\
\hline Sakhalin region & 93.9 & 62.8 & 71.7 & 24.0 & 92.0 & 53.7 & 40.0 & 87.0 & 6808.6 & 70.7 & 67.4 & 77.0 & 75.8 & 84.5 & 1961.6 \\
\hline Krasnoyarsk region & 93.8 & 52.3 & 65.2 & 26.4 & 92.2 & 50.2 & 34.0 & 84.5 & 16890.4 & 68.1 & 63.0 & 69.5 & 66.4 & 81.2 & 1853.8 \\
\hline $\begin{array}{l}\text { Republic of Bash- } \\
\text { kortostan }\end{array}$ & 94.6 & 52.5 & 63.6 & 26.8 & 92.6 & 54.3 & 34.0 & 87.2 & 20802.7 & 73.6 & 62.1 & 77.5 & 72.8 & 91.3 & 1766.3 \\
\hline Samara region & 90.1 & 53.7 & 63.2 & 25.6 & 88.4 & 49.5 & 34.0 & 83.5 & 22167.8 & 66.1 & 73.9 & 76.1 & 72.2 & 85.4 & 1946.3 \\
\hline $\begin{array}{l}\text { Nenets Autono- } \\
\text { mous District }\end{array}$ & 90.4 & 50.5 & 62.2 & 22.9 & 84.2 & 51.4 & 38.0 & 77.4 & 764.1 & 60.4 & 75.7 & 74.8 & 67.5 & 84.6 & \\
\hline Komi Republic & 93.2 & 48.2 & 67.7 & 24.0 & 87.1 & 47.7 & 49.0 & 87.2 & & & 76.4 & 79.0 & 78.8 & 84.1 & 1946.5 \\
\hline Perm region & 93.3 & 57.6 & 66.7 & 38.8 & 90.4 & 42.6 & 36.0 & 87.5 & 19087.0 & 74.1 & 62.6 & 70.3 & 66.9 & 79.4 & 2009.7 \\
\hline Tomsk region & 86.3 & 56.1 & 66.2 & 26.9 & 84.5 & 50.7 & 46.0 & 80.6 & 5806.6 & 66.5 & 64.9 & 73.6 & 72.8 & 83.7 & 1816.9 \\
\hline Udmurt Republic & 96.5 & 53.4 & 67.3 & 22.9 & 93.7 & 55.0 & 31.0 & 88.8 & 6421.4 & 72.4 & 66.5 & 71.4 & 67.9 & 76.7 & 1796.1 \\
\hline Tyumen region & 92.3 & 58.1 & 64.0 & 27.0 & 89.9 & 49.7 & 41.0 & 86.7 & 13864.8 & 72.5 & 67.0 & 68.8 & 66.3 & 89.9 & 2108.2 \\
\hline Omsk region & 90.7 & 48.2 & 57.7 & 22.1 & 88.5 & 44.2 & 50.0 & 83.3 & 5291.9 & 69.8 & 67.7 & 78.2 & 76.6 & 83.4 & 1959.8 \\
\hline Irkutsk region & 88.3 & 47.6 & 57.3 & 26.8 & 85.2 & 45.3 & 34.0 & 79.2 & 13670.5 & 63.7 & 69.1 & 74.5 & 72.8 & 80.5 & 1959.8 \\
\hline $\begin{array}{l}\text { Republic of Sakha } \\
\text { (Yakutia) }\end{array}$ & 93.3 & 44.9 & 53.5 & 22.6 & 88.5 & 42.3 & 32.0 & 80.9 & 8560.8 & 63.9 & 61.4 & 87.6 & 77.8 & 88.1 & 1515.2 \\
\hline Astrakhan region & 95.7 & 53.7 & 68.8 & 26.0 & 93.8 & 51.3 & 32.0 & 89.6 & 3792.9 & 74.7 & 76.1 & 79.5 & 78.8 & 86.9 & 1750.6 \\
\hline Volgograd region & 90.1 & 46.6 & 60.2 & 25.0 & 88.2 & 48.9 & 33.0 & 83.0 & 6303.7 & 68.5 & 67.4 & 78.4 & 77.6 & 85.4 & 1772.4 \\
\hline
\end{tabular}


coke and petroleum products in GRP (the Nenets Autonomous District, Yamalo-Nenets Autonomous District, Khanty-Mansyisk Autonomous District, Tatarstan Republic and the Republic of Sakha (Yakutia)) tend to invest the most in their digital progress. These regions are also the leaders in the majority of digital maturity indicators.

Apart from the above-described methods, there are alternative methodologies for digital transformation assessment:

1. The satellite set of the US national accounts developed by the Bureau of Economic Analysis $(B E A)^{19}$ includes all the goods and services related to digital technologies and is calculated as a percentage of GDP [4].

2. The Digital Economy Satellite Account (DESA) proposed by the OECD (Tatarinov, 2016) can be used to measure the processes of the digital economy and expand the production boundaries by including free digital services into the evaluation.

3. The methodology of calculating GDP by using consumer surplus data (Brynjolfsson, 2017; Nakamura, 2017; Bukht, 2018) is based on estimating and summing up consumer surplus generated from the use of free digital goods and quantifying the adjustment terms that would need to be added to real GDP growth to account for the contributions of these goods.

It should be noted that the above-described methodologies are in fact additional tools for calculating the share of the digital economy in GDP (Brynjolfsson et al., 2019; Brynjolfsson \& McAfee, 2011; Bukht\& Heeks, 2018). There is also a group of integral indices encompassing social and economic indicators that can be used for evaluation. One of such indices is the 'Digital Russia' index developed by the Higher School of Economics, which deals with regional initiatives and their outcomes. The index is calculated by using the following indicators:

- legal regulation and administration;

- workforce and education programs;

- research competencies and technological know-how;

- information infrastructure;

- information security;

- economic indicators;

- social effects.

${ }^{19}$ OECD (2017), OECD Digital Economy Outlook 2017, OECD Publishing, Paris. http://dx.doi. org/10.1787/9789264276284-en
This index is based on expert evaluations of the digitalization in Russian regions. However, it does not pay due regard to the already mentioned prior socio-economic inequalities between these regions. Another disadvantage of this methodology is that all the regions are considered and evaluated separately while many Russian regions in fact share fairly close economic and other ties with their neighbours. Therefore, it would make sense to develop a more general index reflecting the situation on the level of federal districts rather than individual regions.

To measure the spread of digital technologies, the National Research Institute of Technologies and Communications (NIITC) proposed 'Smart Cities Indicators', which are calculated for million-plus cities and comprise 26 subindicators, such as urban environment for research and innovation, public participation in urban planning and management, access to labour market information, development of communications networks for telemetry services, development of systems for environmental monitoring and management, traffic surveillance systems, transparency in public procurement. This indicator can be used to analyze digitalization in large Russian cities, make regional-level estimations and obtain a more detailed picture of digitalization in the socio-economic sphere. The drawback of this indicator is that it uses expert-based evaluations for each of the 26 subindicators, which, together with the lack or absence of some of the data, makes it less accurate and reliable.

A similar indicator - 'Digital Life of Russian Million-Plus Cities' - was developed by the Skolkovo Institute. It reflects the level of digitalization of large cities not only through such 'traditional' indicators as transport, finance, trade, health care, education, media and administration but also provides a surface-level comparison of the digital supply and demand. For example, this indicator shows that the growth in the digital demand exceeds that of the digital supply, especially in the financial sphere due to the economic stagnation and the national regulator's bank merging policy. As a result, some of the regional banks with capabilities in offering digital services had to leave the financial market.

The analysis of the indicators measuring the size of the digital economy through the system of national accounts and integral indices of digital transformation shows that the index system may prove to be quite efficient in the evaluation of di- 
gitalization rates in Russian regions by measuring the extent of digitalization in different socio-economic spheres. Moreover, at the end of 2021, the Ministry of Digital Development in partnership with the Rosatom corporation are planning to present the National Index of Development of the Digital Economy. In our view, it would be a good idea to introduce macro-economic indicators to improve the indices' accuracy and objectivity and to take into account the socio-economic disparities between the regions. Evaluation of the size of the digital sector should also take into consideration added value generated through the implementation of digital solutions in manufacturing and through cost-cutting (production, transaction and other costs).

\section{Conclusion}

Oil and gas regions can become a major driving force behind the digital transformation of the Russian economy. While easily-drilled oil reserves are depleted and oil gets harder and harder to extract, the oil and gas sector is increasingly turning to digital solutions to boost its efficiency and optimize performance. Digital technologies can be applied at all stages of the technological process and thus modernization can encompass a wide range of spheres. Taking into account the share of the oil and gas industry in Russia's GDP, digitalization in this sector can have a significant economic effect.

To accelerate the technological transformation of the oil and gas industry, it is necessary to enhance the level of regional governments' digital maturity of regional, which can be achieved through the improvement of the e-government evaluation systems in Russian regions and by ensuring the compliance of e-government services with the international standards. The crisis caused by the COVID-19 pandemic has also created the need to evaluate the efficiency of public services delivery by regional governments and the overall speed of the digital transformation in the public sector.

In the long-term, in order to achieve a comprehensive multiplier effect, it would be necessary to evaluate all aspects of digitalization to get a fuller picture. The index-based system of integral evaluation holds much promise as long as the existing indices are improved by adding macro-economic indicators and the interregional disparities are taken into account.

\section{References}

Ahmad, N., Ribarsky J., \& Reinsdorf M. (2017). Can potential mismeasurement of the digital economy explain the post-crisis slowdown in GDP and productivity growth? OECD Statistics Working Papers, No. 2017/09, A Publishing, Paris. doi: 10.1787/a8e751b7-en

Ahmed, N., Michelin, R., Xue, W., Ruj, S., Malaney, R., Kanhere, S., Seneviratne A., Hu W., Janicke, H., \& Jha S. (2020). A Survey of COVID-19 Contact Tracing Apps. IEEE Access. doi: 10.1109/ ACCESS.2020.3010226

Akhunov, R.R., \& Nizamutdinov, R.I. (2021). Pandemic crisis in the oil regions of Russia (on the example of the Republic of Bashkortostan). Economics and Management: scientific and practical journal, 3, 159, 4-11. doi: 10.34773/EU.2021.3.1

Akhunov, R.R., Valiev, M.Sh., \& Nizamutdinov, R.I. (2020). Companies of the oil sector during the oil crisis - 2020. Bulletin of USPTU. Science, education, economics. Series: Economics, 4(34), 7-14. doi: $10.17122 / 2541-8904-2020-4-34-7-14$

Barefoot, K., Curtis, D., \& Jolliff, D. (2018). Defining and Measuring the Digital Economy. Bureau of Economic Analysis: working paper, $25 \mathrm{p}$.

Brynjolfsson, E., \& Collis, A. (2019). GDP-B: Accounting for the Value of New and Free Goods in the Digital Economy. UNSW Business School Research Paper Forthcoming, 54.

Brynjolfsson, E., \& McAfee, A. (2011). Race against the Machine - How the Digital Revolution Is Accelerating Innovation, Driving Productivity, and Irreversibly Transforming Employment and the Economy. Lexington, MA: Digital Frontier Press, 98.

Brynjolfsson, E., Collis, A., \& Eggers, F. (2019). Using Massive Online Choice Experiments to Measure Changes in Well-being. Forthcoming, Proceedings of the National Academy of Sciences, 116(15), 7250-7255. doi: 10.1073/pnas.1815663116

Bukht, R., \& Heeks, R. (2018). Defining, Conceptualising and Measuring the Digital Economy. International Organisations Research Journal, 13(2), 143-172. doi: 10.17323/1996-7845-2018-02-07 
Chisadza, C., Clance, M., \& Gupta, R. (2021). Government Effectiveness and the COVID-19 Pandemic. Sustainability, 13, 3042. doi: 10.3390/su13063042

Dmitrievskiy, A.N., Eremin, N.A., Filippova, D.S., \& Safarova E.A. (2020). Digital oil and gas complex of Russia. Georesursy = Georesources, 32-35. doi: 10.18599/grs.2020.SI.32-35

Fang, Z. (2002). E-Government in Digital Era: Concept, Practice, and Development. The International Journal of the Computer, the Internet and Management, 10, 1-22.

Gadzhiev, N.G., Murzak, N.A., Mitenkova, A.E., Skripkina, O.V., Konovalenko, S.A., Hajiyeva, U.A., \& Ismailova, O.S. (2021). Assessment of the prospects for sustainable development in a pandemic. South of Russia: ecology, development, 16(1), 98-109. doi: 10.18470/1992-10982021-1-198-109

Kryukov, V.A., Sevastyanova, A.E., Tokarev, A.N. \& Shmat, V.V. (2017). Modern approach to the development and choice of strategic alternatives for the development of resource regions. Economy of the region, 13(1), 93-105. doi: 10.17059/2017-1-9

Lanshina, T.A., Barinova, V.A., Kondratyev, A.D., \& Romantsov, M.V. (2020). Sustainable development and digitalization: the unusual COVID-19 crisis requires original solutions. Bulletin of International Organizations, 15(4), 91-114. doi: 10.17323/1996-7845-2020-04-05

Levin, S.N., Sablin, K.S., \& Kagan, E.S. (2015). Regions of the 'Resource type' in the modern Russian economy. Journal of Institutional Studies, 9(3), 119-132. doi: 10.17835/2076$\underline{6297.2017 .9 .3 .119-132}$

Nakamura, L., Samuels, J., \& Soloveichik, R. (2017). Measuring the "Free" Digital Economy within the GDP and Productivity Accounts, Economic Statistics Centre of Excellence (ESCoE) Discussion Papers. Working Papers, 17-37, Federal Reserve Bank of Philadelphia.

Ndou, V.E. (2004). Government for Developing Countries: Opportunities and Challenges. The Electronic Journal of Information Systems in Developing Countries, 18.

Seifert, J. (2003). A Primer on E-government: Sectors, Stages, Opportunities, and Challenges of Online Governance, Report for Congress, Retrieved from: http://www. fas.org/sgp/crs/

Shahroz, M., Ahmad, F., Younis, Sh., Ahmed, N., Kamel, Boulos M., Vinuesa, R., \& Qadir, J. (2021). COVID-19 Digital Contact Tracing Applications and Techniques: A Review Post Initial Deployments. Transportation Engineering, 5, 100072. doi: 10.1016/j.treng.2021.100072

Shmal, G.I. (2020). On the new paradigm for the development of oil and gas geology. Georesursy $=$ Georesources, Special issue, 2-4. doi: 10.18599/grs.2020.SI.2-4

Tatarinov, A.A. (2019). Measuring the Digital Economy in National Accounts. Statistics Issues, 26(2), 5-17. doi: $10.34023 / 2313-6383-2019-26-2-5-17$

Zemtsov, S.P., Barinova, V.A., Kidyaeva, V.M., \& Lanshina, T.A. (2020). Ecological Efficiency and Sustainable Regional Development in Russia During the 20 Years of Resource-Based Growth. Ekonomicheskaya Politika = Economic Policy, 15(2), 18-47.(In Russ.) doi: 10.18288/1994-51242020-2-18-47

Zhao, F., Wallis, J., \& Singh, M. (2015). E-government development and the digital economy: a reciprocal relationship. Internet Research, 25(5), 734-766.

Zhiznin, S.Z., Cherechukin, A.V., \& Belodedov, M.I. (2021). A new stage in the competition of minerals in the energy sector in the period after the pandemic, Coal $=$ Ugol, 1, 46-49. (In Russ.) doi: $\underline{10.18796 / 0041-5790-2021-1-46-49}$

\section{Information about the authors}

Rustem R. Akhunov - Dr.Sc. (Economy), member of the Academy of Sciences of the Republic of Bashkortostan, principal researcher, Head of the Laboratory of Modern Problems of Regional Economy, Ufa Federal Research Centre, Russian Academy of Sciences (71, Oktyabrya Ave., Ufa, 450054, Russia); e-mail: akhunov@list.ru

Liaisan R. Akhunova - PhD Student of the Innovation Economy Department of the Bashkir State University (3/4 Karl Marx str., Ufa, 450076, Russia)

Sergey G. Marichev - Junior Researcher of the Centre of Strategic and Interdisciplinary Studies of the Ufa Federal Research Centre, Russian Academy of Sciences (71, Oktyabrya Ave., Ufa, 450054, Russia) 
Rishat I. Nizamutdinov - Junior Researcher of the Centre of Strategic and Interdisciplinary Studies of the Ufa Federal Research Centre, Russian Academy of Sciences (71, Oktyabrya Ave., Ufa, 450054, Russia)

ARTICLE INFO: received July 10, 2021; accepted September 2, 2021

\section{Информация об авторах}

Ахунов Рустем Ринатович - доктор экономических наук, чл.-корр. Академии наук Республики Башкортостан, г. Уфа, Российская Федерация, главный научный сотрудник, зав. лабораторией современных проблем региональной экономики Уфимского федерального исследовательского центра Российской академии наук (450054, Россия, Республика Башкортостан, г. Уфа, пр-т Октября, д. 71); e-mail: akhunov@list.ru

Ахунова Ляйсан Рустэмовна - соискатель кафедры инновационной экономики Баширского государственного университета (450076, Россия, Республика Башкортостан, г. Уфа, ул. Карла Маркса, 3/4)

Маричев Сергей Геннадьевич - младший научный сотрудник Центра стратегических и междисциплинарных исследований Уфимского федерального исследовательского центра Российской академии наук (450054, Россия, Республика Башкортостан, г. Уфа, пр-т Октября, д. 71)

Низамутдинов Ришат Илшатович - младший научный сотрудник Центра стратегических и междисциплинарных исследований Уфимского федерального исследовательского центра Российской академии наук (450054, Россия, Республика Башкортостан, г. Уфа, пр-т Октября, д. 71)

ИНФОРМАЦИЯ О СТАТЬЕ: дата поступления 10 июля 2021 2.; дата принятия к печати 2 сентября 2021 г. 